\title{
The New Perception of the Other in Chipilo, Mexico
}

\author{
Lucia Sbrighi, Louise M. Greathouse Amador \\ and Patricia N. Preciado Lloyd
}

This ethnographic work focuses on Chipilo, a bilingual immigrant community of Italian origin in Mexico that has managed to maintain its dialect and culture for more than six generations thanks to a strong sense and pride of its ethnic identity. Socioeconomic changes and increase in mixed marriages during the last twenty years have affected the process of identity construction. Starting with an analysis of the characteristics that have typically come to define identity and otherness, we examine the new perception of "the other" from the internal perspective of the community. Data derived from a corpus of interviews provide grounds to claim the emergence of a different discourse representation of "otherness" among groups within the same community.

Keywords: Chipilo, Mexico, perception, identity, otherness, immigration.

La nueva percepción del otro en Chipilo, México: El presente trabajo etnográfico se enfoca en Chipilo, comunidad inmigrante bilingüe de origen italiano en México, que ha logrado conservar su dialecto y cultura por más de seis generaciones gracias a un fuerte sentido y orgullo de la identidad étnica. Los cambios socioeconómicos y el aumento de las uniones mixtas de los últimos veinte años han repercutido en el proceso de construcción identitaria. Partiendo del análisis de los rasgos que típicamente han definido la identidad y la alteridad, se examina la nueva percepción del "otro" desde la perspectiva interna de la comunidad. Los datos con base en un corpus de entrevistas evidencian una representación discursiva de la "otredad" distinta en virtud de nuevos elementos que establecen una nueva diferenciación entre grupos dentro de la misma comunidad.

Palabras claves: Chipilo, México, percepción, identidad, otredad, inmigración. 


\section{Introduction}

Francisco Javier Mina, better known as Chipilo, is a town of some 4,000 inhabitants located in the state of Puebla, in the eastern central Mexico. Ever since 1882 when Chipilo was founded as a colony of Italian immigrants from the region of Veneto, in North Eastern Italy, the community has preserved its dialect, as well as its cultural and ethnic identity. Most of the original immigrants came from Segusino and other towns in the northern provinces of Belluno and Treviso. They were a relatively homogeneous linguistic group since they spoke the same variety of dialect at the time of the foundation of the colony. "While the variety of dialect in Segusino is influenced by other Veneto dialects, as well as by standard Italian, the Chipilo dialect in Mexico retains the characteristics of the Basso-Bellunese variety of Veneto spoken a century ago" (Mackay 2002: 30). Moreover, with the passage of time, the Chipilo dialect incorporated lexical borrowing from Spanish.

During Fascism, contact with the homeland strengthened. However, when the fascist period ended in 1945, the initial enthusiasm and strong identification with Italy were replaced by a general feeling of disappointment (Savarino 2006). Later, in 1982, the celebration of the centennial anniversary of the foundation as a colony revived interest for the homeland, increased contact with it and strengthened Chipileñ@s' ethnic identity. On that occasion, there was a cultural interchange between the community of Chipilo and people from the original town of Segusino. For the first time, groups of Chipileñ @s went to Italy to know their ancestors' land and other Italians from the region of Veneto went to Chipilo. They were able to communicate with each other by speaking the same variety of dialect. Interestingly, Chipileñ@s comment that those coming from Italy found that people in Chipilo were speaking like their grandparents, using archaic words, quite uncommon terms, and expressions that are no longer used today in the original towns of the region of Veneto.

Chipilo, the Veneto dialect and the Spanish language are in constant contact and are used in different linguistic contexts. Typically, Veneto is used within the family environment; it is learned in the home and with the members of the community, and for these reasons it has survived and is still widely used today. On the other hand, Spanish is used in formal contexts such as in institutional, educational, and professional environments as well as in interactions with people from outside the group of Chipileñ@s. Chipileño is the name used to refer to the people of this bilingual community of Italian origin. In this article, we use the form Chipileñ@s to refer both to males and females. 
Since the establishment of Chipilo as a colony, the main economic activity of the town has been agriculture and livestock. The Italian colonists brought their knowledge of farming to Mexico and tools necessary to work, but the greatest innovation was to fertilize the soil with cow manure. Livestock farming was a good choice for the Chipileñ@s because it allowed them to differentiate their activities and it gave them wellbeing. Their knowledge of the soil and agricultural in general along with their entrepreneurial spirit allowed them to reach higher economic growth compared to the surrounding villages. As many Chipileñ@s say, they are hard-working, ambitious and saver; for livestock and manufacture of wooden furniture they are supportive and envious. They support each other within the community fot the common good but at the same time they are competitive and always try to do better and be more successful. All these characteristics are part of Chipileñ@s' ethnic, social identity, and of the shared image of their group.

When the colonists arrived in Mexico, it was a type of self-sustaining family and intra-family economy, which limited contact outside the community for a long time since it was based on a tight network of supportive relationships among members of the same group and a strong sense of belonging to the community. Thus, there was no real need to interact with the surrounding villages and the initial geographic isolation of the community favoured endogamy.

Between 1992 and 1999 livestock farming diminished due to insufficient lands, the poor quality of the soil, adverse climate conditions of the area, especially when severe drought or frost ruined the crops. Therefore, Chipilo began to differentiate its productive activity by looking for opportunities outside the community and by investing in carpentry. The manufacture of rustic-style wooden industry was introduced in 1989 with the Segusino factory. It contributed to generate employment and attract labour from the surrounding villages. As a consequence, between 1993 and 1998 there was an increase of furniture factories whose products were exported to Mexico City and other parts of the country, and even abroad. However, at the beginning of the XXI century, the incursion of the Chinese rustic furniture into the marked caused a productive crisis. The Segusino factory failed and caused a return to livestock, the main economic activity of the community. Contact with neighboring towns was intensified and diversified when the Chipileñ@s began to start business, crossing the boundaries between the community and the city of Puebla. The Chipileñ@s became famous for the traditional production of milk, milk products, sausages.

Likewise, as an effect of globalization, the conurbation with the city of Puebla and new immigration flows over the years, the community has been opening to the surrounding areas and has had an impact on its 
inhabitants' lifestyles. Presently, more and more Chipileñ@s work or study in the city of Puebla or in other places in the country. The young people have higher academic preparation in comparison to their grandparents, who in general did not go any further than basic elementary school studies. At the same time, the number of outsiders who live in Chipilo due to the quality of life the town offers, and of those who come and go daily for work opportunities has increased. Consequently, mixed marriages, between Chipileñ@s and outsiders are increasingly more frequent than in the past.

Previous sociolinguistic studies conducted on Chipilo (Sartor and Ursini 1983; Romani 1992; MacKay 1992, 1999, 2002; Meo Zilio 1987, 1995; Barnes 2009 and Tararova 2012, 2017; Fascinetto Zago 2013) have focused on examining the factors that have allowed linguistic and cultural preservation of the community for centuries, among them is endogamy. They have described the contact between Spanish and the Veneto dialect in the community, their domains of learning and use, and the Chipileñ@s' attitudes regarding the use of both languages. They all indicate a deep valuation and appreciation by the Chipileñ@s of their language and traditions, reason for which these authors conclude, with great probability, the dialect and its culture will be preserved in the future.

The image conveyed of Chipilo is that of a quite homogeneous and uniform community that has preserved its uniqueness and peculiarity before the onslaught of time. However, the studies carried out years ago do not consider the recent socioeconomic phenomena in Chipilo and their repercussions on the identity in the bosom of the community. They do not give an account of the current social contact and the complexity of the situation after the opening of the community and the consequent increase in mixed marriages.

Romani (1992: 88) refers to the existence of two poles in Chipilo, that of the ethnic group on one hand, and that of the outside world on the other. The ethnic group and Veneto have been preserved thanks to the family endogamy, for which reason the demonym "Chipileño" indicates the strong correspondence between ancestry, residence and mother tongue, upon designating the Italian descendent, the resident and the language spoken. The dense network of solidary links of relationships due to endogamy, the type of local and family economy of self-subsistence in a reduced territorial environment initially have contributed to strengthening the sense of belonging to the community against the outside world, with which there was not much need to interact. All of this has contributed to consolidating the ethnic identity of the Chipileñ@s as a separate group and their will to transmit the dialect and their traditions to future generations. 
Romani argues that the inevitable opening of the community to the outside world over time would not represent a threat for the ethnic identity. However, the increase in mixed marriages that would cause a change in the dynamics of language transmission, a consequent decrease in the number of its native speakers and a progressive linguistic displacement toward Spanish and the dominant culture of Mexico were foreseen. When the study was carried out, mixed marriages were few and the data indicated a strong continuity of transmission of the dialect and linguistic loyalty.

According to MacKay (1992), after the foundation of the colony, the community of Chipilo remained closed to the outside; the endogamy prevailed because there was little interest to marry members outside the group nor was there the immediate need to integrate themselves into Mexican society. The sense of solidarity and belonging to the group, together with the strong identification with Italian culture, have created a dichotomy between the 'we' ('nosotros') and 'they' ('ellos'), fundamentally for maintaining the ethnic identity and the dialect over time.

After the celebration of the centennial of the foundation of Chipilo in 1982, the young generation seemed more committed and motivated than the previous in keeping the Italian roots, transmitting Veneto and took an interest in preserving it as the language of their ancestors, without code-mixing with Spanish. Efforts have been made to keep the Veneto spoken in Chipilo as well as to develop and standardize a written from of the language. For example, the local group Veneti a Chipilo started publishing the newspaper Al Nostro ("Ours") entirely written in Veneto, for two years approximately. It included stories on local traditions and recipes. Unfortunately, due to lack of funding, the newspaper has been discontinued. However, the group Veneti a Chipilo is still in charge of the organization of Rigoleto, the traditional community game played every year at Easter. In addition, some writers from Chipilo have published books on local history and traditions, such as Los Cuab'tatareme de Chipiloc by Zago Bronca (1998), whose final part includes sections in Veneto, and the collection of short stories in Veneto with Spanish translations Parlar par véneto, viver a Mésico by Montagner Anguiano (2005).

Over twenty years ago, MacKay highlighted two points that could prove to be harmful for maintaining the minority language in the future. These points are the opening of social networks due to the possibilities of employment outside the community on one hand, and the use of the language by the children whose parents do not both speak Veneto on the other, which could indicate a linguistic displacement or even a linguistic change toward Spanish in the future.

Barnes (2009) affirms that the Chipileña identity has been forged and preserved throughout time for generations due to a common ancestry, 
the cultural bond with Italy, the preservation of the physical traits of the ancestors and the constant use of Veneto. These elements, also indicated by Romani (1992) and MacKay (1992) have contributed to preserving the ethnic identity and vitality of the dialect. Barnes concludes the study affirming, along the lines of Romani (1992), that Veneto and Spanish are not two languages in conflict in Chipilo and the separation between the in-group and the out-group is preserved. It is very probable that Veneto is maintained in Chipilo due to the favorable attitudes of the Chipileñ@s toward their language, culture and identity.

Likewise, according to Tararova (2012), the Chipileñ@s make up a homogeneous and separate group regarding outsiders to the community and therefore is a distinction between the in-group, that of the Chipileñ@s on one hand, and an out-group, that of the Mexicans who are not Chipileñ@s, monolingual in Spanish. It recognizes that Chipilo is no longer the closed community of yore and that the identity of the Chipileñ @s has changed in the past years with the entrance of outsiders in the town, whose presence may bring with it a racial mix and the loss of the ethnic identity. Ethnic group, culture and language are the three elements that mark the identification and belonging to the group of Chipileñ@s and that distance them from the out-group of the other Mexicans.

According to Tararova, the contrasts between the in-group and the out-group subsequently raise the defense mechanisms of the Chipileñ@s toward the outside, at the same time would reinforce their own identity and a network of even tighter and more supportive relations within the community. In another study, Tararova (2017) states that the Veneto is still spoken in Chipilo and is learned in the majority of the bilingual families, for which reason the dialect and its culture will most probably be maintained in the next generation due to the vitality and prestige they have in the community.

\section{Hypothesis and objectives}

This work is part of a broader research on discourse construction and negotiation of identity and 'otredad', or the concept of 'other' or outsider, in Chipilo. It intends to analyze how discourse and argumentation of the 'nosotros' ('we') and of the 'ellos/los otros' ('they/the others') which have been formed together with the contrast between past and present that has been changing within the community. The multiplication and diversification of the economic activities in Chipilo in the last twenty years have favored the mobility of its inhabitants and the intensification of the contacts with the outside world. Consequently, it is assumed that in the same way the social context, the lifestyle, interests,

Lengua y migración / Language and Migration 12:1 (2020), 7-35

Edición impresa: ISSN 1889-5425. Edición en línea: ISSN 2660-7166. @ Universidad de Alcalá 
experiences of the Chipileñ@s, which no longer make up such a homogeneous and compact group as in the past have been changing.

Likewise, the individual and social identity of the Chipileñ@s as a separate ethnic group, as well as the perception and representation of the 'other' should be different. The existence of two poles, that of the ethnic group, or in-group, on one hand and that of the outside world, or out-group, on the other, should no longer be as marked. Besides, it is very probable that there are now new different elements between 'what is theirs' and 'what is foreign' that allow the Chipileñ@s to establish distinctions between groups within the same community. The group identity corresponds to the 'si mismo social' (social self) and, together with the individual identity, is the fruit of a construction and participation of the subject within a dynamic of social interaction and negotiation that is developed through time according to the context.

Personal identity always assumes an otherness which is an essential part of human existence: the ' $I$ ' is constantly defined through the relationship with other human beings different from oneself, from our own uniqueness and the distance one takes from all that which is foreign and from the rest. The other then represents the unknown, lo ajeno, the foreign. According to the individual psyche "what is rejected in the other corresponds to something that is his own, not admitted as such by the subject" (Blanck-Cereijido 2003: 27). The human being tends to identify and transfer in the other what is like himself, but unacceptable, in order to protect the image of oneself. It corresponds to what, from another perspective, Goffman (1967) defines with the process of "saving the face", which is of constructing one's own face with the positive traits the person recognizes and claims for oneself. This process arises from the need of the individuals to save their own image in interaction with others. 'The other' is something foreign to the subject, but at the same time not completely foreign; personal identity is constructed through relation and comparison with someone else, where the unacceptable of oneself that is projected on the other is rejected. The awareness of who "the others" are is necessary for the definition of one's own self-awareness.

This study considers that the defensive attitude of Chipilo, as well as the resistance toward everything that represents the foreign nowadays are not as strong as in the past. The progressive opening of the community to its environment and the increase in mixed marriages are evidence of this. Therein lies the importance of creating the study of their own identity and otherness in Chipilo in its current social context. Given the greater presence of outsiders in Chipilo, it is necessary to research if today for the Chipileñ@s 'los otros' (the others) continue to mainly be the other Mexicans or if there are later differentiations, even in the 
bosom of the community itself. Indeed, currently no studies are found that research in depth the range of attitudes of the Chipileñ@s toward their group and subgroups of belonging and the respective construction of identity at a discursive level. As mentioned, the previous sociolinguistic studies have focused on the elements that have characterized the Chipileñ@s as a separate ethnic group and have maintained their union and cohesion over time. The attitudes and uses of the language of the Chipileñ@s toward Veneto and Spanish are essential in order to document the process of acquisition and co-existence of both languages and argue on the possible vitality or loss of the dialect in the future. In this regard, it is important to take into account that how individuals describe language use could be quite different from how it is actually used. Indeed, perceptions about language use as opposed to observation of actual use do not always align. The analysis of attitude and perceptions about language choice and behaviour is central; however, it sometimes accurately reflects them, but at times it does not.

Previous studies generally have not gone beyond this point of inquiry; that is, they have not been guided toward the analysis of the attitudes and perspectives of the members of the original community regarding other topics. Instead, the analysis of the new perception of la otredad, or otherness, in light of recent social changes helps frame the community in current times, to describe, interpret and understand their changes to catch a glimpse of their future. Besides, this work will be useful for the study of other migrant communities throughout the world.

\section{Methodology and corpus}

This work is part of a broader research focused on the discourse construction of identity and otherness in Chipilo (Sbrighi: 2019). The ethnographic approach allows us to describe, analyze and interpret the group of values, beliefs, attitudes of a determined group that shares the same culture (Harris 1968 in Creswell 2007). It also helps to understand the relationship between language, discourse and identity of a community. The participant observation in Chipilo of the subjects of study in daily environments and the periodic interactions with them between the end of 2015 and 2017 was fundamental since it facilitated data collection and the establishment of strong bonds with the Chipileñ@s. Likewise, participation in typical cultural events ( La Befana, el Rigoleto) and occasionally in consular missions and visits to Chipilo by the Ambassador of Italy in Mexico allowed us to appreciate the town's traditions and it was a moment of privileged observation. The Italian precedence of the rese-

Lengua y migración / Language and Migration 12:1 (2020), 7-35

Edición impresa: ISSN 1889-5425. Edición en línea: ISSN 2660-7166. @ U Universidad de Alcalá 
arch undoubtedly has facilitated closeness with the community and the creation of a mutually trusting and accepting relationship.

The data for this study were collected in semi-structured interviews, of which the content and discourse used were analyzed according to the model of analysis of the ethnography of communication illustrated in Kaplan-Weinger and Ullman (2015). There were twelve participants total, of which eight were men and four were women, between eighteen and eighty years of age. Although at the beginning it was assumed that gender would not be a category of prime analysis regarding the objectives of the study, both men and women were interviewed to avoid ruling out a priori data that may be relevant at a later stage. That of age, on the contrary, was a fundamental criterion to be able to document the changes registered in Chipilo in the past ten years and assess the perception of otherness, or 'otredad', among the different generations.

The participants are subjects who were born in Chipilo (those over sixty years of age were born in their house) or in the city of Puebla, who have spent a large part of their lives in Chipilo and at the time of the study lived in the town. The intention was to include subjects who were from the original community and kept bonds alive with them. From the start, it was assumed that the Chipileñ@s who did not live in the town, since they were not in constant contact on a daily basis with their original community, would have a different perspective that did not coincide with the internal perspective of the community.

The main objective has been to examine the internal perspective of the community of Chipilo, especially regarding the perception of otherness. The interviews intended to generate a dialogue from a list of pre-established reflexive questions presented in a certain order. The questions focused on the contrast between the past and the present ('then/now') and the perception of the contrast between the 'we' and the 'they' and of the otherness with its characteristics. The interviews were carried out between March and August 2017, in Spanish, since Veneto is not the mother tongue of the researcher, just as Italian is not the mother tongue of the Chipileñ@s. Indeed, although they do understand Italian, they do not speak it, except those who have studied it for personal interest. The interviews were carried out in person, with appointment, in public, open places and in some cases in the home or workplace of the participants. The duration of these exchanges has been between sixty and ninety minutes. The participants signed an informed consent form and each was assigned a fictitious name to preserve their anonymity and confidentiality of the information given. In the following paragraph, the different voices and opinions of the subjects about the topic researched are given through extracts from the interviews, in Spanish with their respective translation to 
English. For each example, the fictitious name of each participant is given, as can be seen in Table 1 .

As anticipated, some of the assumptions that drove this research are the increase in mixed marriages since this is a recent phenomenon in Chipilo that has affected the configuration of the original group of Chipileñ @s, in the intra- and inter-group interactions and influences in the perception of individual, social and otherness identity (Sbrighi 2018). For this reason, in September 2018 the Civil Registry of the town of Chipilo de Francisco Javier Mina was again consulted. The data from the archive of marriages show that endogamic marriages, that is, among members of the original community of Chipilo are mostly from 1960 to 1999, with the highest percentage (62\%) during the decade $1960-1969$. If the decade 1960-1969 is compared with that of 2000-2009, endogamic marriages have decreased in $36.7 \%$, while mixed marriages have increased in $17.67 \%$. Then if the data from the last 50 years is considered, endogamic marriages have decreased from $70 \%$ in 1968 to $41.66 \%$ in 2017 and to $7.14 \%$ in September 2018. However, exogamic marriages went from only $2 \%$ in 1968 to $58.33 \%$ in 2017 and to $78.57 \%$ in 2018 , registering an exponential increase.

According to participants, when a Chipileñ@ marries someone from outside the community, they almost didn't settle in Chipilo but in Puebla, Cholula or other cities because of their jobs and different interests that make them prefer living somewhere else. However, this is not always the case. It mainly depends on the husband's job, whether or not it is related to the local economic activities, and on the couple's decision.

\begin{tabular}{|l|c|c|c|c|}
\hline \multicolumn{1}{|c|}{ Participant } & Year of birth & Ll & $\begin{array}{c}\text { Language } \\
\text { used at home }\end{array}$ & Highest level of studies \\
\hline Luis & 1985 & Veneto & Veneto & Bachelor's degree \\
\hline Marcos & 1996 & Veneto & Veneto & College student \\
\hline José & 1937 & Veneto & Veneto & Completed elementary \\
\hline Isabel & 1945 & Veneto & Veneto & Completed elementary \\
\hline María & 1973 & Veneto & Veneto & Master's degree \\
\hline Rocío & 2000 & Veneto & Veneto & High school student \\
\hline Lucas & 1988 & Veneto & Veneto & Bachelor's degree \\
\hline Javier & 1989 & Spanish & Spanish & Bachelor's degree \\
\hline Alan & 1991 & Veneto & Veneto & Bachelor's degree \\
\hline Ana & 1950 & Veneto & Veneto & Elementary \\
\hline Juan & 1960 & Veneto & Veneto & Middle school \\
\hline Pedro & 1984 & Veneto & Veneto & Bachelor's degree \\
\hline
\end{tabular}

Table 1. Participants of the study

Lengua y migración / Language and Migration 12:1 (2020), 7-35

Edición impresa: ISSN 1889-5425. Edición en línea: ISSN 2660-7166. @ Universidad de Alcalá 


\section{Results and discussion}

In line with our hypotheses, the "other" in Chipilo for the original Chipileñ@s who live in the town, continues being above all the outsider, that is, the "Mexican Mexican" as the participants say, who was born in Mexico, not of Italian ancestry. Although Mexico is home of an extraordinary cultural diversity, Chipileñ@s consider themselves as a separate group in Mexico and tend to distinguish themselves from those who do not share their ethnic roots, nor their entrepreneurial spirit in general. Even when dealing with outsiders who come and go daily for work or who have settled in the town, they are always seen as outsiders in some way and as a separate group. Regardless, younger and older people coincide in identifying certain characteristics in the 'other'. They are people who move to Chipilo for the work opportunities or for the better quality of life and tranquility the town offers in contrast to the city of Puebla, for example.

The labels used by Chipileñ@s in their discourse to refer to the 'other', that is, the outsiders are chicho/chicha, chichet, mesican, piot. Each term has different nuances: mesican is the Mexican from the city of Puebla, chicho is the Mexican from the countryside or the surrounding villages, with certain physical traits and dark skinned. According to MacKay's dictionary (2017), chicho is used to refer to indigenous people in a derogatory way. While piot means 'turkey'; however, apart from this literal meaning reported in the dictionary, the term actually has a figurative meaning as well in Veneto. According to Chipileñ @s, it has the same sense of chicho, but is charged with a much stronger pejorative connotation. Indeed, they inform they used it amongst themselves to make reference to outsiders with certain feelings of disdain and anger. In other contexts, chicho o mesican are more common instead (Sbrighi 2018: 208).

They are considered 'different' since they have a different mentality, way of being and culture. If outsiders do learn Veneto, it sounds different or is strange, as Javier responds to the question, "When an outsider speaks Veneto, how do you feel?":

(1) De cierta forma me sorprende que lo aprendan [...] $\underline{\text { Pero }}^{1}$ no lo bablan igual porque no tienen ese...como entonación que es donde más se nota. Por ejemplo, en año nuevo cuando se va a pedir dulces temprano síllegan niños de los pueblos del alrededor. A muchos les molesta, a muchos les molesta, como que invadan las tradiciones de acá. A un grupo adulto. A lo mejor, no adultos mayores. Adultos como de 30 a 50. Los que llamamos los papás, a esa gente le molesta. Y también gente más o menos de mi edad, que dicen "es que no deberian de hacer". Pero también hay perso- 
nas a las que le da gusto que tengan ese interés, ese cariño por las tradiciones de acá. Cantan un véneto que no es véneto. Se oye feo porque no es ni siquiera cercano a las palabras, a cómo se entona cada palabra. Lo que es bonito es que les interesen las tradiciones y lo que se vive acá y que se integren. (In a certain way I am surprised they learn it [...] But they don't speak it the same because they don't have that ...like intonation, which is what stands out most. For example, at New Year when they go to ask for candy, children from surround towns come. Many of them get upset, they get very upset, as if the traditions from here are invading. A group of adults. Maybe, not senior citizens. Adults from 30 to 50. Those we call parents, they get upset. And, people around my age, who say, "they shouldn't do that." But there are also people who are happy they have that interest, that fondness for traditions from here. They sing a Veneto, which is not Veneto. It sounds terrible because it does not even come close to the words, to how each word is intoned. What is nice is that they are interested in the traditions and in the experiences here and they become part of it.)

For the interviews, the main effects of opening of the community at a social level have been the arrival of more outsiders and, consequently, the increase in mixed marriages. The contrast between 'then' and 'now' is more evident and from there the generational contrast is more marked than in the past. Younger and older folks recognize that previously Chipilo was very closed compared to today. Ana comments:

(2) Ya estamos muy ${ }^{\circ}$ mezclados ${ }^{\circ}[. .$.$] antes los viejitos no dejaban entrar a la$ gente a la zona de aqui... mis padres y mis abuelos...y también los...por ejemplo mi esposo... en esa época no dejaban que entraran mucho porque los esperaban y le daban en la torre (se rie). Y aborita, ¿sabes qué? Que la amistad de los jóvenes con los de afuera ya es mucha. Sí, es difícil ya que se mantenga... Y ¿sabes qué también aparte? Que hay mucha...o sea, que hay fuente de trabajo, hay mucho trabajador por las carpinterias, por el campo y que el campo ya lo están echando a un lado, eh... ya no quieren, quieren dedicarse más a los estudios. Se salen a buscar otras cosas, pero "(pausa)" eso es lo que pienso... y los terrenos...por ejemplo, mira, todos los que son como yo legítimos de aquí, nos vamos muriendo y las casas las van ocupando por ejemplo mi nieto que... a lo mejor se casa con una persona que no es de aqui. Y asi se va yendo, por eso te digo que dentro de diez años no creo que... (We are now very ${ }^{\circ}$ mixed $^{\circ}[\ldots]$ previously the old folks didn't let people come into this zone ...my parents and my grandparents... and also the ... for example, my husband... in that time they did not let many people in because they would wait for them and give them a beating (laughter). And now, you know what? There is a lot of friendship between the young people and those outside. Yes, it is difficult to maintain nowadays... And, you know what else? There is a lot... I mean, there is a source of work, there are a lot of workers because of the carpentry shops, because of the farming and that they are not

Lengua y migración / Language and Migration 12:1 (2020), 7-35

Edición impresa: ISSN 1889-5425. Edición en línea: ISSN 2660-7166. @ U Universidad de Alcalá 
farming anymore ...they don't want to do it anymore; they want to study more. They leave to look for other things, but "(pause)" that is what I think... and the land...for example, look, all those who are like me are from here, we are dying and they start using the things, for example, my grandson who...maybe he will marry a person who is not from here. And that's how they start leaving, that's why I say within ten years I don't think that...)

Juan says:

(3) "Antes se les abría la puerta a una persona que viniera a vivir a Chipilo después de::: años de tratarla y de saber cómo es. Abora les venden hasta el terreno y no les importa quién sea con tal de venderle el terreno". ("Previously they would open the door to a person to come live in Chipilo after:: years of dealing with him/her and knowing what he/she is like. Now they sell them the land and they don't care who it is, as long as they can sell the land.”)

Likewise, Pedro, gave his answer to the question: "Has there been any change in the community in the past ten years?" as follows:

(4) Bastante... la presencia de personas que no son de origen chipileño, que no son de origen véneto ha permeado la mayor parte de la interacción social que existe entre las personas, empezando por la lengua que tiende cada vez más hacia el español más que el véneto precisamente por la presencia de estas personas que no hablan véneto, que son monolingües en español. Y además el cómo se percibe a la sociedad a nuestro alrededor; hace 10 años todavía habia cierto hermetismo ante, digamos, todas las personas que no eran propias de aqui. Ahora se ha vuelto muchísimo más común el que sean aceptadas personas del exterior. $Y$ además, la cultura digamos la más común en México que tiende hacia actividades como por ej. los bailes, la música, lo que le sucede a una persona, lo que es popular, es más común, especialmente entre los jóvenes. (Quite a bit... the presence of people who are not of Chipileño origin, who are not of Veneto origin have permeated the main part of the social interaction before people, starting with the language which each day tends to move toward Spanish more than Veneto, precisely due to the presence of these people who do not speak Veneto, who are monolingual in Spanish. And besides how one sees society around us; ten years ago, there was still a certain impenetrability regarding, let's say, all the people who were not from here. Now it has become much more common that these people from outside are accepted. And besides, culture, let's say, the most common in Mexico moves toward activities like, for example, dances, music, what happens to a person, what is popular, more common, especially among the young people.)

What distinguishes the young people from the older people (parents, uncles and aunts, and grandparents) is the perception toward change 
that has arisen within the community. According to them, since its opening, Chipilo has lost its essence and the outsiders represent a threat, whose presence could compromise the preservation of the ethnic identity and the dialect in the future. Contrarily, the young generation (1830 years of age) considers this change to be normal and even necessary and it was drive by the young people themselves, as Rocío observes:

(5) La sociedad ya está más abierta. Antes era como más rústico, por llamarlo así, más cerrado y aborita ya está empezando a abrirse [...] yo creo que los jóvenes han provocado que sus papás se empiecen a abrir y de abi los abuelos. Siento que hay 2 opciones. O que desaparezca Chipilo como tal o que se abra todavía más, que sea más conocido y crezca. Síporque como es hoy, si sigue así, como ni muy abierto ni muy cerrado, está como intermedio, entonces siento que, si sigue así, sí se va a perder. Entonces creo que debería abrirse mas no perder su origen. Porque la técnica de encerrarse ha funcionado, pero en su momento, aborita pues todo está creciendo y si no nos abrimos, si no aceptamos eso, creo que se va a perder más. (Society has opened more. Before it was like more rustic, to call it that, more closed, and now it is starting to open [...] I think the young people have made their parents start to open up and consequently their grandparents, too. I feel there are two options. Either Chipilo disappears as such or it opens up even more, it be more known and grow. Yes, because as it is today, if it continues like that, like not open but not closed, it's like intermediate, then I feel that, if it continues like this, it will be lost. Then I think it should open more but not lose its origin, because the technique of closing itself off has worked, but at the right time; now everything is growing and if we don't open up, if we don't accept that, I think it is going to lose itself even more.)

The older folks interviewed, even though mixed marriages are becoming more frequent in Chipilo, warn of certain problems since a spouse who is an outsider has a different mentality. The concern is linked to the possible loss of the Veneto language in the short and medium term, since there will be a greater tendency to speak Spanish at home. Contrarily, for young people like Alan, the increase in exogamy is inevitable:

(6) Antes Chipilo era un pueblo celoso, o sea, nosotros nos casábamos entre chipileños, llegaba gente de fuera y pues de aquí los corríamos porque éramos celosos, a la gente de fuera la corríamos porque éramos celosos con nuestras mujeres y ya no, ¿por qué? Porque no puedes parar eso. Tarde o temprano tiene que...tiene que llegar a Chipilo... (Previously, Chipilo was a jealous town, meaning we married among Chipileñ@s, people came from the outside and we would run them out because we were jealous, we would run the outsiders out because we were jealous about our women, but not anymore. Why? Because you can't stop this. Sooner or later it has to ... it has to come to Chipilo...)

Lengua y migración / Language and Migration 12:1 (2020), 7-35

Edición impresa: ISSN 1889-5425. Edición en línea: ISSN 2660-7166. @ Universidad de Alcalá 
his young participant expressed his point of view, different from that of the majority or from the most conservative participants, from which he moves away, referring to 'them' instead of including himself. For him, the others are people who belong to the in-group of the Chipileñ@s:

(7) Pues, yo no veo mal que entre gente a Chipilo. Sí hay personas foráneas que entran a Chipilo y vienen a aportar, pero no todos los chipileños somos iguales. O sea, hay de los que sí dicen "ah, pues sí, qué aporten, ¿no? está viviendo por aquí, está viviendo por Chipilo" cuando muchos de Chipilo no hacen eso. Después ves eso de una persona foránea que de un chipileño. $Y$ aparte no todos los foráneos son iguales. Entonces que ahi entra en disputa el tema. Entonces yo sí estoy de acuerdo que, si quieren ayudar a Chipilo, pues adelante. Pero hay otros chipileños que no. O sea, el racismo, no tanto el racismo, sabes, el "mejor hacerlo entre nosotros. A lo mejor él nos va a dar la espalda porque nos es de Chipilo". yo lo veo bien, pues porque trato con ellos, con mis vecinos. Me abro a las opiniones, a los foráneos... (Well, I don't see any harm in people coming into Chipilo. If there are outsiders who enter Chipilo and come to contribute, but not all the Chipileñ@s are the same. I mean, there are those that say, "Oh, well yes, that they contribute, right? They are living here, they are living in Chipilo" when many from Chipilo do not do that. Later you see that from an outsider instead of from a Chipileño. Also, not all outsiders are the same. That is where the topic comes into discussion. So I agree that if they want to help Chipilo, go right ahead. But there are other Chipileñ@s that do not. I mean, racism, not so much racism, you know, the idea "better to do it by ourselves". Maybe he will turn his back on us because he is not from Chipilo. I see it well, since I deal with them, with my neighbors. I am open to the opinions, to the outsiders...)

The recent opening of Chipilo is accompanied by a change in perspective and interest of the Chipileñ@s, above all among the young people. Regarding mixed marriages, Luis shares the opinion of others of his age, a group with which he identifies ('we') and moves away from the more closed-minded Chipileñ @s ('they'), according to him:

(8) En mi caso y yo creo que la mayoría de la gente de mi edad no lo vemos como mal...es algo normal, la cuidad va creciendo y la gente en Chipilo va teniendo más estudios y también yo creo que ayuda a abrirse puertas $y$ a no tener los ojos vendados... digo, es parte del crecimiento y de la cotidianidad de una población que ha sido cerrada toda la vida. Entonces yo considero, bueno, a mi parecer, según mi punto de vista que es algo que forma parte de la evolución de Chipilo. Eso es...es normal. (In my case and I believe the majority of the people my age do not see it as bad... it is normal, the city is growing and the people in Chipilo have more studies and I also believe that it helps to open the doors and to not have 
blinders on... I mean, it is part of growth and of the daily life of a town that has been closed its entire life. So, I think, well, in my opinion, according to my point of view, that it is something that forms part of the evolution of Chipilo. That is, it is normal.)

Not only the older folk, but also the young people recognize the economy of the town has diversified and it is no longer based mainly on livestock. The interests are different and go beyond the boundaries of the community, as Marcos indicates:

(9) Es un precedente muy fuerte el de los matrimonios mixtos que hay en la comunidad sobre todo porque la mira es hacia salir. $Y$ entonces porque realmente en esta comunidad si no tienes un vínculo fuerte con la tierra, es decir, si no eres ganadero, si no eres ranchero, etcétera no hay nada que te ate aqui. (It is a very strong precedent, that of mixed marriages in the community, above all because the goal is toward leaving. And then because really in this community if you do not have a strong bond with the land, meaning if you are not in livestock, if you are not a rancher, etcetera, there is nothing to tie you here.)

Currently, the young people have a higher level of studies in comparison to their parents and grandparents. They speak more languages and their greater academic preparation is valued by the community in general as social advancement, as María comments.

(10) Los jóvenes están ya estudiando y ya están cambiando su mentalidad. Antiguamente, era nada más trabajar en las vacas y habia vacas nada más y por supuesto trabajando en las vacas, iban a estudiar por la tarde y olian a... a veces no les daba tiempo ni de bañarse porque se levantaban temprano, iban a la escuela y olian a vaca [...] Muchos chipileños han cambiado de oficio, ya no tienen vacas, abora hacen muebles, eso cambió, le dio un cambio y ya los jóvenes estudian, la mayoría salen a estudiar, hacen su carrera universitaria y eso ha cambiado, ha cambiado, ha cambiado, entonces no sé si llegue el día de la más aceptación de los chipileños. Por ejemplo, abora, sobre todo las mujeres. Se están casando mucho con hombres de la alta sociedad de Puebla, se está dando mucho, cuando antiguamente no se daba eso. $Y$ son mujeres que estudian, que saben más idiomas, más cultas. (The young people are studying and changing their mentality. In the old days, it was just working with the cows and there were only cows and nothing more and of course, working with the cows. They would study in the afternoon and they smelled of ... sometimes they did not have time to bathe because they got up early, and they would go to school smelling of cow [...] Many Chipileñ@s have changed trades, they don't have cows anymore, now they make furniture, that changed, it changed the town and now the young people study, the majority study outside of the

Lengua y migración / Language and Migration 12:1 (2020), 7-35

Edición impresa: ISSN 1889-5425. Edición en línea: ISSN 2660-7166. (C) Universidad de Alcalá 
town, they study university and that has changed, it has changed, it has changed, then I don't know if the day will come of more acceptance by the Chipileñ@s. For example, now, especially women. They are marrying more with men from the high society of Puebla, it is happening a lot, when that wasn't done in the old days. And they are women who study and they know more languages, they are more educated.)

The interviewees over 40 years of age focused on a change in values and customs through which the generational contrast has become more evident. They see the young people as a different group outside the group of Chipileñ@s. At a linguistic level, such differentiation is marked by the temporal and personal deixis with the use of the pronoun 'they' in contrast with that of 'we'. To the question about changes seen in the social environment in the last ten years in Chipilo, several participants comment on the topic of technology and its repercussion in interpersonal relations. In this regard, Ana states:

(11) La juventud que...la tecnología, las escuelas, todo...como que están más despiertos más... (se ríe) y nosotras pues estuvimos nada más hasta sexto de primaria. Todas no teníamos ingresos como para ir a estudiar a otro lado, aparte no teníamos con qué movernos [...] aborita la juventud me doy cuenta de que busca otros niveles de vida y también ha entrado mucha gente que no conocemos y se hacen amigos de la juventud y no sabe uno con quién anda [...] aborita con la tecnología ya somos burritos. Ya ha cambiado, ya no sabemos nada de eso. Yo veo a mis nietos... iuy!? esto (indicando mi celular) lo manejan como si fuera... la computadora, tienen, todo. ¿sabe qué? Me doy cuenta de los defectos, serán defectos, que ya no son costumbres, la culpa mucho ya la tienen los papás porque se les da todo en charola de plata, los consiente uno mucho.(The youth that... technology, schools, everything...they are like more awake more ... (laughter) and we well studied only up to sixth grade in elementary. We didn't all have income to go study somewhere also, nor did we have ways to get there [...] now the youth, I realize, look for other lifestyles and a lot of people come in we don't know and they make friends with the young people and we don't know who they are hanging out with $[\ldots]$ now with the technology we are donkeys [ignorant]. Things have changed; we no longer know any of that. I see my grandchildren... Oy! This (pointing at my cell phone) they work it as if it were... the computer, they have, everything. You know what? I realize the flaws, they will be flaws, that are no longer customs, the parents are at fault because they give them everything on a silver platter, they spoil them a lot.)

For Ana the belonging and identification of the group of her contemporary Chipileñ@s are very strong. She does not speak in first person singular, but rather about 'we', including herself, the ' $\mathrm{I}$ ', and comprising her 
social and collective identity as a member of her group she evokes in her discourse, even though it is not present at the time she speaks.

Isabel comments:

(12) Los jóvenes ya no le tienen respeto a la gente, en cambio nosotros, como los de mi edad y eso, a las personas mayores ya le teníamos mucho respeto, mucho "(pausa)". Pero ahorita ya no, ya $a^{2}$... le vale "(pausa)" [...] dicen que es por todas partes. Que todos están desenfrenados. Y ya uno no puede ni hablarles con esto porque se "(pausa)" aíslan. Ya pues no convive uno? Yo lo veo con mi nieto "(pausa)", entra, está bablando (hace el gesto de hablar con el celular), al rato, abi está. jdeja eso y vamos a comer! Déjalo, descansa, descansa. Lávate tus manos, vamos a comer, descansa esa cosa. Ya, me hace caso un rato, pero no termina de poner el último, que ya, ya. Tiene ...vicioio [...] Todo el día está hablando por teléfono, todo el día...esas cosas, nosotros no las conocíamos, no... conviviamos. [...] Los jóvenes van y vienen, pues ya les gusta ya allá hay más oportunidades, ya se encuentran que la novia, que esto y que el otro, y ya se van ${ }^{3}$ y abi se quedan, en Puebla y ya no regresan. Chipilo ya está mezclado mucho y antes no dejaban entrar a nadie. Nadie entraba $a^{4}$. (The young people no longer respect people; however us, like those of my age and that, we have a lot of respect for our elders, a lot "(pause)". But now, no longer, ...now, they don't care "(pause)" $[\ldots]$ they say it is everywhere. That everyone is out of control. And you can't talk to them anymore because they "(pause)" they isolate. One does not co-exist anymore? I see with my grandson "(pause)" he comes in, he's talking (gesturing for talking on the cell phone), a while later, there he is. Leave that and come eat! Leave it, rest, rest. Wash your hands, let's eat, give that thing a rest. He pays attention a little while, but is son back on it, give it a rest, he says, give it a rest. He has::: a vice [...] All day he is talking on the phone, all day...those things, we did not have them, no... we co-exist. [...] The young people come and go, they like it where there are more opportunities, they meet up with the girlfriend, they do this and do that, and they leave and they stay there, in Puebla, and they don't come back. Chipilo is already mixing a lot and before they didn't let anyone in. No one entered.)

Even though the generation gap and the impact of the extensive use of technology are not specific to Chipilo, actually they are evident and significant. Traditionally, Chipilo has been characterized by a tight network of supportive relationships among families and members of the same group and a strong sense of belonging to the community. The impact of globalization and technology into the local community highlights a change in mentality and lifestyle across generations. Young generations aspire to a global modern lifestyle and are no longer attrac-

Lengua y migración / Language and Migration 12:1 (2020), 7-35

Edición impresa: ISSN 1889-5425. Edición en línea: ISSN 2660-7166. @ U Universidad de Alcalá 
ted by the rural life and traditional activities of Chipilo. Hence, the generation gap also stresses the change of identity from rural to urban and shapes different socio-cultural practices. Moreover, the use of technology has an effect on the language use as well. Despite the efforts to develop a written standardized form of the language, Veneto is mainly an oral language. For this reason, younger participants notice that the language they use on facebook, whatsapp and social networks in general is not Veneto, but Spanish. They did not know how to write it correctly, and prefer to switch to Spanish in order to avoid misspelling and misunderstanding.

Additionally, the young people also distance themselves from the previous generations upon recognizing, from their point of view, that their interests are different, as Javier affirms with the repeated use of the adverbs 'outside' [afuera] and 'no longer' [ya no]:

(13) La gente joven ya no se ve comprometida a ayuda acá, sino les interesa trabajar afuera, estudiar afuera, divertirse afuera [...]Yo me siento como alguien que está perdiendo el véneto y sus tradiciones. Porque ya mi interés no está en quedarme acá. Ya no está en desenvolverme acá y tampoco vivir. A la larga, mis objetivos están en desempeñarme en la gran ciudad. The young people are no longer committed to helping here, but rather they're interested in working outside, studying outside, having fun outside [...] I feel like someone who is losing the Veneto language and its traditions. Because my interest is no longer in staying here. It is no longer in working here nor in living here. On the long term, my objectives are working in the big city.

Rocío highlights that today the tendency of the young people is to leave Chipilo in search of more attractive opportunities:

(14) Nuestra sociedad aborita, la chipileña...yo he visto que busca...como más, metas más altas, como crecer más, pues tener otro punto de vista, otra oportunidad se puede decir, porque mis abuelos, aunque quisieran, no tuvieron la oportunidad de ir a estudiar fuera, conocer más idiomas... Entonces eso socialmente yo creo que ha hecho un impacto enorme. Y esto también provoca que se esté perdiendo un poco pues las tradiciones, todo... [...] He pensado salir de Chipilo porque siento que me ayudaría a crecer. Salir a Puebla es otra cosa, creo que me ayudaría, pues no sé, a crecer [...] Y puede tener muchísimos beneficios si nos sabemos abrir. (Our society now, that of Chipilo... I have seen searching... like more, higher goals, how to grow more, to have another point of view, another chance we could say, because my grandparents, even if they wanted, did not have the chance to study outside, to learn more languages... Then that socially I think that has been an enormous impact. And that too caused it to be losing a little the traditions, 
everything... [...] I have thought about leaving Chipilo because I feel that it would help me grow. Leaving for Puebla is one thing, I think it would help me, well I don't know, to grow [...] And it can have very many benefits if we know how to open.)

Within the same generation, one can see different attitudes toward the development of their own community and its possible preservation in the future, above all among the young people. On one hand, as said by Javier, some admit that their personal and professional interests are no longer in Chipilo, since they feel it is not sufficiently broad to develop themselves in. At the same time, they realize that the lack of interest toward their town will in the future bring a loss of the Veneto language and of the sense of their traditions.

On the other hand, other young people, such as Marcos, Alan and Lucas, move away from that attitude and criticize their contemporaries who do not commit themselves to Chipilo and who, according to them, lack awareness of the value of their own roots, of solidarity and unity, therefore causing a lack of continuity with the past. Alan is convinced of the importance that there are young professionals like him residing in Chipilo and are at the service of the community:

(15) A mi me gustaría seguir con todo lo que es de Chipilo y quedarme aquí. Tengo un despacho, trabajo con gente de Chipilo y todos están muy agradecidos. Mucha gente dice qué bueno que hay alguien que estudió porque no muchos estudiaron antes. Entonces dicen qué bueno que haya alguien de aqui que haya estudiado, que sepa, que nos eche la mano, porque le tienen la confianza, porque saben que eres de aqui. (I would like to continue with everything Chipilo is and stay here. I have an office, I work with people from Chipilo and everyone is very thankful. A lot of people say it is good that someone studied because not many studied here before. Then they say it's good that there is someone here who studied, who knows, who helps us out, because the trust is there, because they know you are from here.)

Marcos speaks of the lack of awareness of the new generations with which he does not identify, using the alternate form 'we' instead of 'they':

(16) Las nuevas generaciones no se conciben como chipileñas porque no tienen la consciencia de lo que implica ser chipileño. En general, el compromiso con mantener vivo el dialecto, incluso con las costumbres, eso no implica que no vayan a las fiestas y a las tradiciones, sino que implica que van, pero meramente por lo lúdico [...] Algo interesante es que las nuevas generaciones, si me incluyo a mi y a todos los que tienen 30 para abajo, pocos, pero varios, hemos sentido la necesidad de teorizar

Lengua y migración / Language and Migration 12:1 (2020), 7-35

Edición impresa: ISSN 1889-5425. Edición en línea: ISSN 2660-7166. @ Universidad de Alcalá 
todo el fenómeno de vida del chipileño, como parte de nuestro compromiso. (The new generations think of themselves as Chipileñ@s because they are not aware of what it means to be Chipileño. In general, the commitment to keep the dialect alive, even with the customs, that does not imply that they don't go to parties and participate in traditions, but rather it implies they go, but only as recreation [...] Something interesting is that the new generations, if I include myself and everyone under 30 years of age, few, but several, we have felt the need to theorize the whole phenomenon of life from Chipilo, as part of our commitment.)

Lucas takes a certain distance from the young Chipileñ@s regarding the tendency in constant increase of mixed marriages, above all among the women, according to him:

(17) Son más las mujeres que tienden a casarse con gente de fuera que los chavos. Ahi sí no sé... dicen hasta que la gente de fuera dice que no somos muy románticos, que nos lo ban dicho de hecho, somos más cerrados, gente más dura nosotros y que por eso van con la gente de fuera. Sí nos lo han dicho. Prefieren la gente de fuera porque les bajan el sol y la luna, la verdad hasta las ilusionan mucho, también eso. Prefieren eso, aunque seamos trabajadores o si que somos responsables y que sí nos importan ellas, aunque no lo expresemos. Sí nos importan, pero no, prefieren a alguien que se lo esté diciendo. (It is the women who tend to marry people from outside more than the men. There I do not know... they say, even the people from outside say that we aren't romantic, they have told us in fact, we are more closed, more hardened people and that is why they go with people from outside. They have told us that. They prefer people from outside because they give them the sun and the moon, they really get their hopes up, they do that. They prefer that, even though we are hard-working and we are responsible, and we do care for them even though we do not show it. We do care, but no, they prefer someone who is always telling them how much they care.)

However, to the question: "If you had to choose your partner, would you prefer her to be from Chipilo?", Lucas confirms that he would like to marry a Chipileña or, even better, an Italian.

'The others' within the community for the young and the older folk are also the Chipileñ@s who speak the dialect less and less or speak only Spanish, a new phenomenon which causes concern. To the question: "When your son/nephew/grandson/original members of the community do not speak the dialect, how do you feel?” Ana comments:

(18) Me da tristeza... siento tristeza. Por ejemplo, tengo tres sobrinos que viven en Puebla, ellos lo entienden, pero no lo hablan. No lo bablan...y 
si hablan oyes muy diferente. También los de aquí, la mamá no es de aqui y mis sobrinos lo entienden, pero no lo hablan. Después mis sobrinos se casaron con gente que no es de aqui... se va perdiendo. (It makes me sad... I feel sadness. For example, I have three nephews who live in Puebla; they understand it, but they don't speak it. They don't speak it... and if they do speak, it sounds very different. Also those from here, the mother is not from here and my nephews understand it, but they don't speak it. After my nephews got married with people not from here... it is being lost.)

Isabel states her concern because her grandchildren no longer speak Veneto, something that was not very common in Chipilo:

(19) Mi papá y mi mamá en nuestros tiempos, no babia uno que hablara español. No. Ahorita también les están metiendo las mamás modernas el español, jestando aqui en Chipilo! Tengo una nieta y le hablan en español. Y yo les digo: “¡No le hablen en español!”. (My father and my mother in our days, there wasn't a one that spoke Spanish. No. Now the modern moms are speaking Spanish to them, being here in Chipilo! I have a granddaughter and they speak to her in Spanish, and I tell them, “Don't speak to her in Spanish!”)

José adds that even the outsiders who live in Chipilo are surprised that the Chipileñ@s have stopped speaking their dialect:

(20) Hay gente que no es de acá y que ha aprendido a hablar el dialecto y esos lo sienten más que lo vayan perdiendo. Porque dicen: "Yo no soy de acá y lo aprendí. ;Ellos que son de acá y lo van perdiendo!”. Si, hay gente que hasta les reclama y les dice: "¿̇ं̇oye y por qué???”. (There are people not from here and who have learned to speak the dialect and they feel even more that it is being lost, because they say, "I'm not from here and I learned it. They are from here and they are losing it!" Yes, there are people who even complain, and they say to them, "Hey, but why???”)

Juan says it is a more common tendency among young people:

(21) Desde hace unos diez años, en las escuelas ya no les permiten hablar en dialecto. Entonces los niños cuando te llegan a la casa ya te hablan en español. Ya no te hablan en dialecto [...] Y los jóvenes, como ya saben el dialecto, no les interesa conservarlo. Aprenden inglés, alemán, otro idioma". (Since about ten years ago, in the schools they no longer allow them to speak the dialect. Then the kids when they get home they speak to you in Spanish. They don't speak to you in the dialect anymore [...] And the young people, since they don't know the dialect, they are not interested in preserving it. They learn English, German, another language.)

Lengua y migración / Language and Migration 12:1 (2020), 7-35

Edición impresa: ISSN 1889-5425. Edición en línea: ISSN 2660-7166. @ U Universidad de Alcalá 
From the interviews it was seen that today in Chipilo a differentiation is made among the group of young people. Those from 18 to 30 years of age see a distance with those younger, under 18, which represents another facet of the otherness within the community. Lucas expresses his surprise and incomprehension regarding the children who do not speak the dialect and at the same time reiterates its importance and their pride at speaking it:

(22) Los niños están ya dejando de hablar el dialecto. Y muchos hasta se avergüenzan de hablarlo. Cuando a mí al contrario me da orgullo, me agrada mucho hablarlo la verdad. Pero sí veo mucho ya que, por ejemplo, que tengan los papás de Chipilo los dos pues ya los niños hablan en español y no quieren hablar el dialecto. Les da como vergüenza, pues en la escuela be escuchado que se burlan por como hablan. Y entonces ya no les gusta hablarlo por eso. Entonces, se van al español, se van. Que eso cuando yo era niño, pues era inormal!, platicábamos, en lo que hacíamos a los profesores porque no nos entendian y hasta nos agradaba. Pero como que abora les da más vergüenza. (The children have already stopped speaking the dialect. And many are even ashamed to speak it. I, on the contrary, am proud of it. I am very pleased to really speak it. But, yes, I see it a lot, for example, that they have parents from Chipilo, both of them, and the children speak Spanish and do not want to speak the dialect. They are ashamed of it since in school I have heard they make fun of them because of how they talk. So they do not like to speak it because of that. So they go toward Spanish, they go. When I was a child it was normal! We would chat, about what we did to the professors because they didn't understand us and we even liked it. But it seems now they are more ashamed.)

In the interviews, the young people recognize in the older folk, especially the grandparents, the merit of having preserved and transmitted the Veneto language for generations in "a pure form" as they say, that is, without mixing it with Spanish.

\section{Conclusions}

The previous studies on Chipilo have described a homogenous, uniform and relative stable community in the time it has been able to preserve thanks to its clear identity and the pride for its uniqueness, its dialect and its culture. Over time, the ethnic identity of the Chipileñ@s has been forged on the value of what is its own and the defensive attitude toward the outside. Since its establishment as a colony, Chipilo has been characterized by the presence of two separate and well-differentiated poles, that of the community on one hand, and the world outside of it 
on the other. Even the relationships in the in-group of the Chipileñ@s and with the out-groups have been established around this dichotomy.

However, the socioeconomic changes in the past twenty years, inside and outside Chipilo, have produced important transformations in the social fabric of the community and have inevitable repercussions at its level of sociolinguistic identity, in a manner different from conceiving oneself and the otherness. Indeed, in Chipilo, the other and the others were typically those that belonged to the outside world, those considered outsiders, who occupied a physical space and different meaning. They lived outside the town; they had other physical traits, a different way of being and traditions. This study offers an updated view of Chipilo from the internal perspective of the community.

Without distinction of gender, for the Chipileñ@s today, the other by antonomasia continues to be the outsider; that is, s/he does not originate in Chipilo, although s/he has come to establish him/herself in the town. However, the results from the qualitative interviews reflect a perception of the different otherness, more complete and exhaustive. Behind the opening of the community to the surrounding towns, the arrival of outsiders, the recent increase in mixed marriages, the community is no longer as homogeneous as it was in the past. The otherness acquires more facets and is not only outside the community of origin. According to the perception of the participations, 'the other' is someone who is now closer, who belongs to the same community.

The study of the language used by the participants allowed examination of the topics discussed in the interviews, to individualize the categories of analysis of this study, as well as to contrast the different points of view. 'The other' is the person seen as different from oneself or who adopts a different attitude or opinion regarding the social identity of the Chipileñ@s as a group. Such distinction may be seen at a linguistic level through the use of pronouns. Under the label of 'we' the Chipileñ@s use in general to share values, norms, a territory and a past with which the community identifies, a differentiation is seen. For the participants from 18 to 30 years of age, the use of the 'we' corresponds to 'we, the young Chipileñ@s' who have a higher level of studies compared to the generations of their parents and grandparents. They have a more open mind about recent social changes happening in Chipilo and they promote their evolution. They show a positive attitude toward the change and mixed marriages; they move away from the older adults and their closed mind. On the other hand, the participants older than 40 years old caution on the detachment with the new generations regarding values, thought and lifestyle. Consequently, the generational contrast is evidenced in the discourse of the interviewees through a pronominal structure of chiasmus: 'we' the elders of Chipilo, direct witnesses of the evolution of Chipilo faced with 
'they, the others', the young people of today, comprising those genuinely interested in the maintenance of Veneto and the younger ones (under 20) who speak the language of the community less and less.

Indeed, the social deixis "allows one to not only select the actors, but rather to also characterize them socioculturally. The social deixis states the identities of the persons of the discourse and the relationship between them and the (possible) audience" (Calsamiglia and Tusón, 2012: 146).

If the generational gap can characterize any community in the world, it is also true that, with the recent social phenomena that have been stressed more in Chipilo, where their defensive attitude, certain impenetrability and internal cohesion have allowed its preservation throughout time. This work also evidences that the contrast is not only between grandparents and grandchildren, but also at an apparently less notorious level, between those from 20 to 30 years of age and those that are younger. Today, those under 20 years of age often come from mixed family nuclei; they understand the dialect, but they speak it less or they do not speak it at all, which is a new and significant social phenomenon. The young people in general, less bonded to the legacy of their ancestors, have other interests and aspirations that go beyond the community boundaries and they are more open to change.

Not only the older folk, but also the young people interviewed generally in their narration keep a distance from the Chipileñ@s who show less attachment to the town's traditions and less interest in speaking and transmitting the Veneto language, even when they continue participating in cultural community events. It is noted that the ideas and preferences verbally expressed do not always correspond to what they really do. Likewise, 'the others' are considered the Chipileñ@s who marry outsiders.

The increase in mixed marriages generates certain concern since endogamy traditionally had been a fundamental factor for the preservation of the ethnic identity and the linguistic and cultural transmission for centuries. As reported by participants, Spanish is manly or exclusively spoken in exogamous families. According to participants in another recent study focused on the Chipileñ@s' attitudes towards the increase of mixed unions (Sbrighi 2018), it is more likely that children learn Veneto in the home if the mother is from Chipilo. Indeed, mothers usually spend more time with children who receive more linguistic 
input in the mother tongue. In some cases, the foreign partner manages to learn Veneto, $s /$ he understands it but rarely speaks it for the fear of making mistakes with native speakers.

However, as Sbrighi (2018) highlights, contrary to previous studies on Chipilo, even when the mother is Chipileña, Veneto language transmission is not guaranteed. Due to some attitudes towards women, the outsider spouse may prefer Spanish to be spoken at home rather than the dialect he doesn't understand, and even prohibits Veneto as a form of exerting control on the wife and the family. Moreover, the mothers from Chipilo themselves sometimes give up speaking Veneto to their offspring because they tend to appreciate more learning of Spanish as dominant language and of other official languages. In any case, at the moment there is no quantitative data available about which languages different couples use with their children at home and the domain of learning and use of Spanish and Veneto respectively. Therefore, further research should also focus on the number of non-Veneto speaking spouses who actually learn Veneto once they have moved to Chipilo.

Following up with our discussion, for the young generations, it is important to recognize the points of continuity and rupture with the past since the future of Chipilo depends on them. The new representation and differentiation of 'the other' may be understood in some way as a defensive distancing strategy from what is not recognized as their own and may compromise the uniqueness. The perception of 'otherness' is expressed in the discourse of the participants in a constant coming and going between the 'we' and 'they, the others'. Similarly, the 'chipileñeidad' is constructed around the image of oneself and of the 'other', in a continuous moving away and coming back from the center (we) and from the periphery (the others) linguistically evidenced with the use of the adverbs of place 'here' and 'there' and the verbs of movement 'go', 'leave' and 'come'. The spatial deixis contributes to identify two spaces, not only physical, but also imaginary, as well as to socioculturally characterize the individuals who live in them. Each participant is identified by some aspect with the group of the Chipileñ@s in general, opposing the other Mexicans in general and at the same time, it is recognized, and distance is taken regarding the subgroup of belonging, according to the cases (for example, the older to the younger and vice versa).

The concept of identity is dynamic; it is modified throughout time and in regards to the context (Wodak 2009). Social or group identity is subjective as personal identity. According to Van Dijk (2000: 160), "social identity as a socially shared mental construct also allows individual variations in interpretation, historic changes in the meaning of the external manifestations of social identity". In the case of Chipilo, the 
construction of individual identity and group identity are modified with the social stimuli and pressure that come from the outside and with the changes that occur within the community. Likewise, the perception of 'otherness' changes. In the discourse of the Chipileñ @s interviewed, a polyphony is noticed, that is, a plurality of voices and points of view different within the same group of original members of the community.

The advanced idea in this study is the 'nosotredad' which arises in the bosom of the community, understood in terms of valuation of 'nosotros- los otros' (we-the others) and assumes a new re-creation of the collective identity. This concept introduced in the doctoral thesis (Sbrighi 2019) includes the different facets of the ethnic identity and integration of aspects of the miscegenation of the two cultures in contact, the Chipileña of Italian origin on one hand, and the Mexican on the other. The 'nosotredad' is part of the complexity of the identity phenomenon in minority communities and deserves to be seen as an element contributing to the cultural richness in the everyday multicultural world. The Chipileñ@s are aware of these identity changes within their group. The 'nosotredad' does not assume less authenticity of the ethnic identity itself and should not be an obstacle for the preservation of the community in the future. The challenge is to recognize it as an essential trait of the current group identity where diversity is the fruit of its evolution and is considered a wealth. From there we have the importance of researching deeper the 'nosotredad' in Chipilo and comparing it to other migrant communities in the world.

\section{Lucia Sbrighi}

Instituto de Ciencias Sociales y

Humanidades

"Alfonso Vélez Pliego"

Benemérita Universidad Autónoma

de Puebla (BUAP), México

Av. Juan de Palafox y Mendoza 208,

Centro Histórico de Puebla,

72000, Puebla, México

lucia.sbrighi@gmail.com

ORCID: 0000-0002-3721-0349
Louise Mary Greathouse Amador

Instituto de Ciencias Sociales y

Humanidades

“Alfonso Vélez Pliego"

Benemérita Universidad Autónoma

de Puebla (BUAP), México

Av. Juan de Palafox y Mendoza 208,

Centro Histórico de Puebla,

72000, Puebla, México

louisa33@mac.com

ORCID: 0000-0002-7057-9068

Patricia N. Preciado Lloyd

Instituto de Ciencias Sociales y Humanidades "Alfonso Vélez Pliego"

Benemérita Universidad Autónoma de Puebla (BUAP), México

Av. Juan de Palafox y Mendoza 208, Centro Histórico de Puebla,72000, Puebla,

México

patriciapreciado@hotmail.com

ORCID: 0000-0002-2048-0756

Recepción: 08/12/2018; Aceptación: 20/04/2019 


\section{Notas}

1 For the transcription conventions see the Annex.

2 Upset tone.

3 Certain tone of disapproval and inconformity.

4 Certain tone of sadness and yearning.

\section{References}

Barnes, Hilary. 2009. A Sociolinguistic Study of Sustained Veneto-Spanish Bilingualism in Chipilo, Mexico. Dissertation Doctor of Philosophy. Pennsylvania : The Pennsylvania State University.

Black-Cereijido, Fanny and Pablo Yankelevich. 2003. El otro, el extranjero. Buenos Aires: Libros del Zorza.

Calsamiglia, Helena and Amparo Tusón Valls. 2012. Las cosas del decir. Manual de análisis del discurso. Barcelona: Ariel.

Creswell, John. 2007. Qualitative Inquiry and Research Design: Choosing among Five Approaches. Thousand Oaks, CA: Sage.

Fascinetto Zago, Karina. 2013. Elección lingüistica bilingüe (Véneto-español): El caso de Chipilo, Puebla, Dissertation Master of Arts in Ciencias del Lenguaje. Puebla, Mexico: Benemérita Universidad Autónoma de Puebla.

Goffman, Erving. 1967. "On face work". In: Interaction ritual: essays on face to face behavior, 5-46. New York: Pantheon.

Harris, Marvin. 1968. The rise of anthropological theory: a history of theories of culture. New York: T. Y. Crowell.

Jefferson, Gail. 2004. "Glossary of transcript symbols with an introduction". In: Conversation Analysis: Studies from the First Generation, Gene H. Lemer (ed.), 1323. Philadelphia: John Benjamins.

Kaplan-Weinger, Judith and Char Ullman. 2015. Methods for the Ethnography of Communication. Language in Use in Schools and Communities. New York: Routledge.

MacKay, Carolyn J. 1992. "Language maintenance in Chipilo: a Veneto dialect in Mexico". International Journal of Social Language, 96. 129-145.

MacKay, Carolyn J. 1999. "Dos casos de mantenimiento lingüístico en México: el totonaco y el véneto". In: Las causas sociales de la desaparición y del mantenimiento de las lenguas en las naciones de América. Anita Herzfeld and Yolanda Lastra, (eds), 77-98. Sonora, México: Universidad de Sonora.

MacKay, Carolyn J. 2002. Il dialetto veneto di Segusino e Chipilo. Cornuda-Treviso: Grafiche Antiga.

MacKay, Carolyn J. 2017. El véneto de Segusino y Chipilo. Fonología, gramática, léxico véneto, español, italiano, inglés. Puebla, Mexico: Benemérita Universidad Autónoma de Puebla.

Meo Zilio, Giovanni. 1987. "Lingue in contatto: interferenze fra veneto e spagnolo in Messico”. In: Presenza, cultura, lingua e tradizioni dei veneti nel mondo, parte I: America Latina, Giovanni Meo Zilio, (ed.), 237-263. Regione Veneto: Centro Interuniverisario di Studi Veneti.

Meo Zilio, Giovanni. 1995. Estudios hispanoamericanos. Temas literarios y estilísticos. Roma: Bulzoni Editore.

Montagner Anguiano, Eduardo. 2005. Parlar par véneto, víver a Mésico. Puebla, Mexico: Conaculta-Scp.

Poland, Blake D. 2002. "Transcription quality”. In: Handbook of Interview Research: Context and Method. Jaber F. Gubrium and James A. Holstein (eds.), 629-650. Thousand Oaks, CA: Sage.

Lengua y migración / Language and Migration 12:1 (2020), 7-35

Edición impresa: ISSN 1889-5425. Edición en línea: ISSN 2660-7166. @ C Universidad de Alcalá 
Romani, Patrizia. 1992. Conservación del idioma en una comunidad italo-mexicana. México: Instituto Nacional de Antropología e Historia.

Sartor, Mario and Flavia Ursini. 1983. Cent'anni di emigrazione. Una comunità veneta sugli altopiani del Messico. Cornuda-Treviso: Grafiche Antiga.

Savarino, Franco. 2006. Un pueblo entre dos patrias. Mito, historia e identidad en Chipilo, Puebla (1912-1943). Cuicuilco, 13:36. 277-291.

Sbrighi, Lucia. 2018. "El aumento de las uniones mixtas en Chipilo, México: actitudes y percepción identitaria en una comunidad inmigrante de origen italiano". Cuadernos Aispi, 12. 191-214. Doi: 10.14672/0.2018.1495.

Sbrighi, Lucia. 2019. Construcción discursiva de la identidad propia y de la nueva percepción del otro en Chipilo, México. Dissertation Doctor of Philosophy in Ciencias del Lenguaje. Puebla, Mexico: Benemérita Universidad Autónoma de Puebla.

Tararova, Olga. 2012. A Study of In-group and Out-group attitudes in an Italo-Mexican Community, Chipilo. Dissertation Master of Arts in Latin American and Caribbean Studies. Guelph: The University of Guelph.

Tararova, Olga. 2017. "Language is me: language maintenance in Chipilo, Mexico". International Journal of the Sociology of Language, 248: 25-48. Doi: 10.1515/ijsl2017-0029.

Van Dijk, Teun Adrianus. 2000. Ideología. Una aproximación multidisciplinaria. Barcelona: Gedisa.

Zago Bronca, José Agustín 1998. Los Cuah'tatarame de Chipiloc. Chipilo, México: Edición de autor.

Wodak, Ruth et al. 2009. The Discursive Construction of National Identity. (2nd ed.) Edinburgh: Edinburgh University Press.

Annex: Transcription conventions

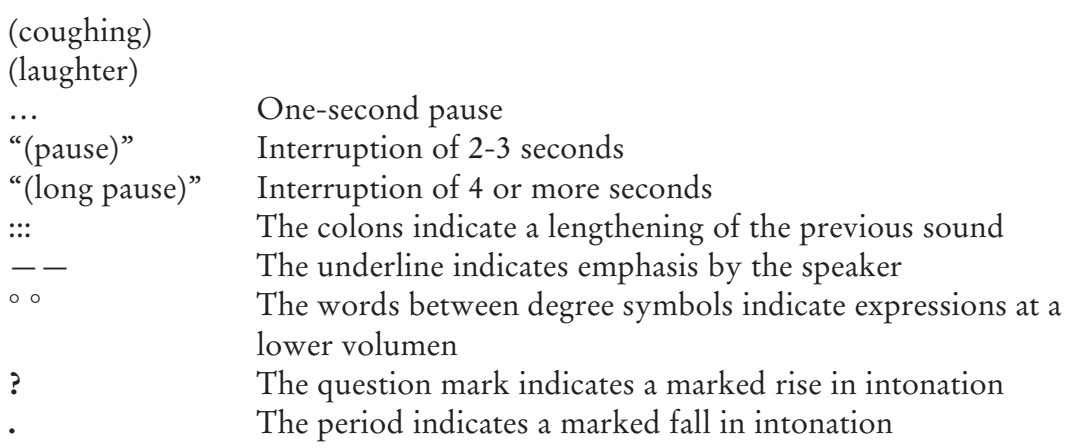

Adapted from Jefferson (2004) and Poland (2002: 641) 